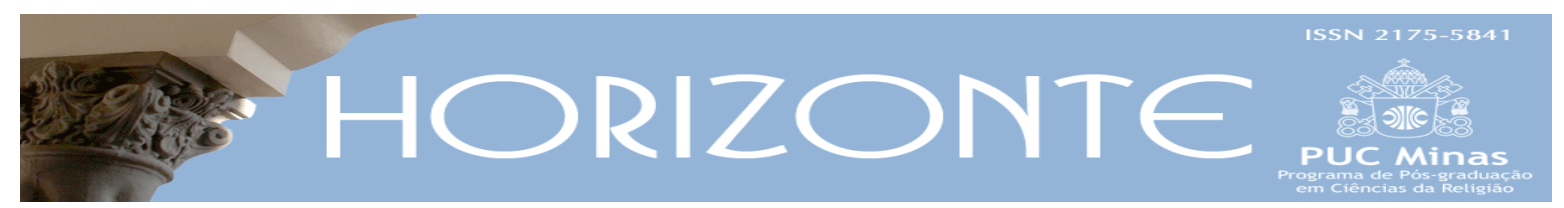

Dossiê: Narrativas Sagradas e Linguagens Religiosas - Artigo Original ๑。

DOI - 10.5752/P.2175-5841.2016v14n42p473

\title{
Data, autor e local do Livro de Eclesiastes
}

\author{
Date, Author and Place of the book of Ecclesiastes
}

\section{Resumo}

Jorge Luis Gutiérrez*

O objetivo do presente artigo é fazer uma proposta sobre qual foi a data em que o livro bíblico do Eclesiastes (קהלת na sua forma hebraica) foi escrito, quem foi seu autor e o local em que foi escrito. Temas que sempre estiveram envoltos em acentuadas discussões no mundo acadêmico relacionado com a pesquisa bíblica. Em cada um dos itens que nos propomos abordar, e as respectivas perguntas que pretendemos responder, começaremos revisando criticamente as propostas que tem sido feita pelos principais pesquisadores destes temas, em diferentes épocas e lugares. Para logo, a partir delas fazer uma proposta sobre os três temas que abordamos neste artigo: a data, o autor e o local do livro de Eclesiastes. Nossa conclusão é que a redação do livro de Qohélet aconteceu por volta do ano 250 a.C., sua autoria não pode ter sido de Salomão, mas de alguém que viveu no norte da palestina, na fronteira linguística com aramaico.

Palavras-chave: Eclesiastes, Bíblia, Qohélet, Literatura hebreia, Antigo testamento.

\begin{abstract}
The purpose of this article is to put forth a proposal regarding at which date the Biblical book of Ecclesiastes (קהלת in its Hebrew form) was written, who its author was and at which place it was written. Such themes have always been shrouded in fierce discussions in the academic world connected to Biblical research. In each of the items we propose to touch upon, and the respective questions we intend to answer, we shall start by critically reviewing the proposals that have been made by the main researchers of such themes, at different times and places. Afterwards, based on them, we shall put forth a proposal regarding the three themes we deal with in this article: the date, the author and the place of the Book of Ecclesiastes. Our conclusion is that, given the fact that the Book Qohélet was written around the year of 250 B.C., it could not have been authored by Solomon, but by someone who lived in Northern Palestine, at the linguistic border with the Aramaic.
\end{abstract}

Key words: Ecclesiastes, Bible, Qohélet, Hebrew literature, Old Testament.

\footnotetext{
Artigo recebido em 08 de dezembro de 2015 e aprovado em 10 de junho de 2016.

* Possui doutorado em Lógica e Filosofia da Ciência pela Universidade Estadual de Campinas (1993) e mestrado em Lógica e Filosofia da Ciência pela Universidade Estadual de Campinas (1990). Possui cursos de especialização em Israel e Chile. Atualmente é professor da Universidade Presbiteriana Mackenzie, professor da Faculdade de São Bento e professor visitante da Universidad de Concepción de Chile. País de Origem: Chile. E-mail: jorgelrg@uol.com.br
}

Horizonte, Belo Horizonte, v. 14, n. 42, p. 473-496, abr./jun. 2016 - ISSN 2175-5841 


\section{Introdução}

A bíblia é uma coleção de livros escritos por vários autores em diferentes épocas e lugares. Assim, entre outras possibilidades, a Bíblia pode ser considerada como literatura e, consequentemente, pode ser estudada com os mesmos métodos que são estudadas outras obras literárias.

Quem foi o autor? Quando foi escrito cada livro? E em que local? Tem sido objeto de controvérsias desde os tempos antigos. Isto, principalmente, porque muitos livros não têm nenhuma informação sobres estes tópicos, ou informação insuficiente e indireta. Mas também, às vezes, ainda que a informação esteja no texto, ela deve ser analisada criticamente e avaliada à luz de outras fontes e assim tentar entender o que significa essa informação e como deve ser analisada, especialmente quando ela parece ser contraditória, inverossímil ou pouco provável.

Assim, no presente artigo, propomo-nos definir, até onde seja possível, a data, o autor e o local onde foi escrito o livro de Qohélet (em hebraico) ou Eclesiastes (em português).

Para isso, analisaremos as evidências dentro do próprio livro (internas) e a literatura que há sobre estes temas. Assim, por exemplo, um aspecto importante para determinar a data, é analisar a língua em que este livro foi escrito e a que época ela corresponde. Como também analisar se o filho de David, que reinou sobre Jerusalém, do qual se faz menção no começo do livro, pode ser Salomão, ou é um pseudepígrafe, ou seja, uma falsa alegação de autoria que deve ser analisada e colocada na justa medida. Pesquisaremos estes e outros aspectos com o maior cuidado possível.

E finalmente nos perguntaremos se sobre estes temas podem ser obtidas conclusões claras e definitivas, ou se elas sempre deixarão lugar à dúvida e à incerteza. 
Nossa pesquisa será, basicamente, bibliográfica. Através da leitura das obras dos principais pesquisadores, tentaremos chegar às conclusões que nos pareçam mais verossímeis e prováveis.

\section{0 título e o autor do livro de Eclesiastes}

O título do livro em hebraico é Qohélet, (קהלת). O significado desta palavra é obscuro e seu sentido original foi-se perdendo com o transcurso dos séculos. Isto faz com que as interpretações e traduções deste termo sejam variadas, polêmicas e desencontradas. Então, numa primeira tentativa de encontrar o significado desta palavra, listaremos as sete vezes que ela aparece no livro:

1,1 Palavras de Qohélet, filho de Davi, rei em Jerusalém.

1,2 Hebel, ${ }^{1}$ diz o Qohélet, hebel, tudo é hebel.

$1,12 \mathrm{Eu}$, Qohélet, fui rei de Israel, em Jerusalém.

7,27 Vê o que eu encontrei, disse Qohélet.

12,8 Hebel hebelim, disse o Qohélet, tudo é hebel.

12,9 E Qohélet foi mais que um sábio e ensinou ao povo.

12,10 Qohélet procurou descobrir o prazer e alegria das palavras.

Em nível mais elementar e técnico, podemos estabelecer que o sufixo desta palavra corresponde a um particípio feminino da raiz qahal (קהל): convocar, reunir a assembleia. Assim, Qohélet pode ser traduzido como o que fala ante a assembléia. Nada indica que se trate de uma assembleia religiosa ou litúrgica, ou que o autor estive-se investido de um cargo sacerdotal. Como também nada faz pensar que o que o Qohélet falava eram sermões ou pregações, pelo contrário, sua

\footnotetext{
1 “Hebel" é, possivelmente, a palavra mais característica do livro de Qohélet. É o famoso Vaidade, da frase "Vaidade das vaidades, diz Qohélet, vaidade das vaidades, tudo é vaidade". No livro de Gênesis "hebel" é o nome do filho e Adão e Eva, é a mesma palavra. Sobre o significado desta palavra podemos citar o dicionário de Schökel: sopro, vento, suspiro; vazio, nada, vacuidade, irrealidade, vaidade, ilusão; fatuidade; fantasma; ídolo. (SCHÖKEL, 1994, p. 190).
} 
fala estava mais perto dos discursos ou aulas dos mestres de sabedoria. Possivelmente se trata de algum tipo de Assembleia do povo.

A palavra Qohélet pode também ser traduzida simplesmente como assembleia, ou seja, tratar-se-ia da designação metonímica de seu portador, isto é, aquele que a reúne ou a ela se dirige, o homem da Assembléia, ou simplesmente “o Assembleia”. Ou seja, a palavra Qohélet serve para designar um homem, sendo que primeiramente servia para descrever uma atividade ou um ofício, servindo posteriormente para designar o respectivo depositário. Qohélet se refere, consequentemente ao ofício de dirigir a assembleia ou de falar nela e, depois, à pessoa do dirigente ou do orador da mesma. Chegando até a se transformar em nome próprio.

Também é possível que a palavra קהלת seja um acróstico, seguindo a analogia de Pr 30,1, onde o nome para o pai de Agur (ykh, יקה) é um acróstico de três consoante (ykh, יקה = yhwh qados hu). Porém nenhuma resposta satisfatória tem sido encontrada para as quatro palavras que começariam com as quatro consoantes de Qohélet.

No passado, muitos comentaristas entenderam a palavra Qohélet como pregador. Este significado, expressado na tradução da Septuaginta como Ekklesiastés, que a Vulgata simplesmente transliterou, pode também ser encontrado na Midrash Rabba, e foi adotado por muitos tradutores e comentaristas posteriores, como por exemplo Lutero (Der Prediger). Outros mantiveram o Ekkesiastes da Septuaginta, mas acrescentaram a tradução. Assim a King James Version colocou "Ecclesiastes or The Preacher" e a Reina-Valera "Eclesiastés o El Predicador".

Apesar do sufixo feminino, os verbos que acompanham a palavra Qohélet são de regência masculina, sendo a única exceção 7,27. Então, significa esta regência feminina que quem está falando é uma mulher? Não necessariamente, pois existem na Tanak outros casos de nomes masculinos que têm sufixo feminino 
(assim, por exemplo I Cr 7,8). Também algumas vezes a designação de certos ofícios tem sufixo feminino. Um exemplo disto são os textos de Ez 2,55.57 para se referir à ocupação de escriba e Ne 7,59 para caçador de gazelas. O primeiro tem relevância, se consideramos o nome Qohélet como um nome próprio, e o segundo, se o consideramos como uma ocupação. Porém se consideramos Qohélet como um ofício ou função, temos o problema de que isto não concordaria com o cargo de rei que o próprio Qohélet diz ter.

O sufixo feminino estaria, então, indicando a função, e não a pessoa que realiza esta função, e foi usado, possivelmente, para sinalizar a solenidade do cargo. Também não se pode afirmar que a forma feminina da palavra é por causa de que quem está falando é a Sabedoria, muitas vezes personificada como mulher (especialmente em Pr 8). Porque se for assim, a regência verbal do contexto deveria ser também feminina e não masculina como está no texto. Igualmente deve ser rejeitada a hipótese de que a palavra Qohélet é um erro de tradução de um particípio aramaico masculino.

Sobre o texto de 7,27 pensamos, não sem bastante receio, de que se trata de um erro textual: a palavra Qohélet tinha originalmente artigo, e este foi colocado por erro no verbo anterior. A favor disto está que em 12,8 se encontra a mesma forma, ou seja, o Qohélet com artigo e o verbo no masculino. Nossa opção tem também o apoio da Septuaginta e praticamente de toda a tradição.

A Septuaginta transformou sempre a desinência feminina em masculina e traduziu, na totalidade das vezes, esta palavra pelo substantivo "ekklesiastes" da raiz "ekklesía", que era a assembleia do povo ou uma reunião convocada. Essa forma dos tradutores gregos foi adotada pela maioria das traduções modernas.

A tese da autoria salomônica do livro, tão difundida no judaísmo como no cristianismo até o século XIX, hoje é rejeitada por muitos pesquisadores, 
estabelecendo-se quase um consenso de que não pode ter sido Salomão o autor do livro. Ou como disse Haroldo de Campos:

Atualmente todos os exegetas de certo renome concordam que se trata do recurso literário da "pseudo-epigrafia", vale dizer: a atribuição, à obra de um autor obscuro, do nome de uma personagem ilustre, seja para lhe conferir mais peso e credibilidade, seja para seguir uma convenção em moda na época. (CAMPOS, 1991, p.99).

Porém, quem foi o primeiro a perceber que Salomão não poderia ter sido o autor de Qohélet foi Lutero. Ele disse em suas “Conversas de Mesa”:

Que o próprio Salomão não escreveu o livro de Eclesiastes, mas ele foi produzido por Sirach na época dos Macabeus (...) Ele é um tipo de Talmud, compilado de muitos livros, provavelmente da biblioteca do rei ptolomeu Euergetes do Egito. (BARTON, 1908, p.21).

A hipótese da autoria salomônica do livro surgiu na tradição da sinagoga e rabínica a partir da leitura de 1,1, onde se afirma que Qohélet foi filho de Davi e rei em Jerusalém (também em 1,12). Assim uma fonte rabínica afirmava que Salomão escreveu o Cântico dos Cânticos, com sua ênfase no amor, em sua juventude; Provérbios, com seu acento nos problemas práticos, em sua média idade; e o Qohélet, com sua melancólica reflexão sobre a vaidade da vida, em sua velhice. (Midrash: Shir Hashirim Rabba 1:1). (GORDIS, 1951, p. 39).

O lugar que o livro ocupa na Tanak também é revelador, pois ele foi colocado entre Provérbios e Cantares, livros que começam atribuindo a Salomão sua autoria (Ct 1,1; Pr 1.1; 10,1; Sb 25:1).

Assim podemos afirmar que Salomão é simplesmente um pseudônimo atribuído pela tradição rabínica, e posteriormente adotada pelo cristianismo, a partir do redacional texto de 1.1.

Ou, quiçá, a tradição atribuiu a autoria do livro a Salomão, possivelmente, para seguir um velho costume egípcio, que fazia os mestres de sabedoria descenderem de antigos reis. (SELLIN-FOHER, 1977, p. 500). 
A própria data em que o livro foi escrito (como veremos a seguir) já seria suficiente argumento para tirar seu caráter salomônico, especialmente porque o hebraico do livro representa um estágio bastante tardio da língua, impossível na época de Salomão.

Mas, principalmente, há o forte argumento de que Qohélet nunca se chama a si mesmo "filho de Davi". O texto de 1.1, igual a tantos outros cabeçalhos dos livros da Tanak, ${ }^{2}$ é claramente redacional. Quase com certeza esta afirmação do editor foi baseada em 1,12, onde o Qohélet, falando na primeira pessoa, afirma: “Eu, Qohélet, fui rei em Jerusalém”. Ou seja, a ficção literária do autor foi só se atribuir o título de rei e não de Salomão. O autor não usa o pseudônimo Salomão, como fizeram outros autores da época, como, por exemplo, o autor da "Sabedoria de Salomão" e dos “Salmos de Salomão".

Para o Qohélet era suficiente se apresentar como rei. Aliás, os livros de sabedoria não foram assinados pelos seus autores. As autorias atribuídas nos cabeçalhos são do editor. Uma exceção foi a "Sabedoria de Jesús Ben Sirac”. Uma outra exceção poderia ser Qohélet, pois em 1,12 o autor se chama a si mesmo por este nome. As outras vezes $(1,1.12 ; 7,27 ; 12,9.10)$ são redacionais.

O texto de I Rs 8,1s, no qual Salomão fala ao povo em assembleia, também tem sido evocado para afirmar que o rei Salomão era um "Qohélet". Neste texto, a raiz verbal usada para referir-se à reunião que fez Salomão na ocasião da dedicação, é a mesma raiz da palavra Qohélet.

Porém, a partir das fortes críticas que Qohélet faz do poder real, e a falta de sentido que ele vê na sua vida de rei, podemos ver, na afirmação de que ele é rei, muito mais um sarcasmo e uma irônica acusação contra o reinado. 
Um outro argumento para retirar a origem salomônica do livro são os textos de 1,16 e 2,7 em que pode ser deduzido que houve muitos outros reis predecessores em Jerusalém e não só um - David - como se de fato se tratasse de Salomão. Também em 1,12 é usada uma forma "completa" (passado) do verbo ser, ou seja, ele foi, mas não é mais - "eu, Qohélet, fui rei sobre Israel" - o que certamente não poderia ser dito por Salomão. Soma-se a isto que em 8,2 e 10,16 se fala do rei em terceira pessoa, pelo que pareceria que não é o próprio rei que está falando. Aliás, é só até o capítulo 3 que se fala do autor como sendo rei, a partir deste capítulo ele aparece muito mais na condição de súdito.

Por outro lado, se abandonamos a tradição judaica e cristã que leu por séculos MLK como "rei", e lemos esta palavra com um de seus outros sentidos, teremos não um rei mas simplesmente um "proprietário". Esta hipótese elaborada por Ginsberg, seguida por Haroldo de Campos, 3 é passível de ser confirmada tanto pelo dicionário Gesenius como por Koehler-Baumgartner. Sobre isto Haroldo de Campos comenta que a arte já "copidescou" a vida e a história, e que o provável autor verídico do Qohélet, membro de uma família proeminente e homem de elevada ilustração, tanto judaica como helenística, vivendo cerca do ano 250 a.C., cedeu definitivamente sua pessoa física à "pessoa" fictícia de Salomão, o construtor do Templo e a Sabedoria personificada. (CAMPOS, 1991. p. 99).

Ao atribuir uma autoria salomônica ao livro, o editor fez uma crítica aos governantes da época. Canaã havia voltado a ser o que fora na época de Salomão: um território onde a monarquia vivia cheia de privilégios e abundância, e o povo era cada vez mais pobre. Possivelmente aquilo que o Qohélet só esboçou e disse entrelinhas o editor colocou com toda clareza: a vida sob uma classe governante de cultura grega fazia lembrar a dura época do reinado de Salomão. 4 Mas, por outro

\footnotetext{
${ }^{3}$ Embora Campos comente que «A força fabuladora no tempo já preencheu de um conteúdo indelével o dado agora arqueologicamente restituído, não sendo mais possível substituir, sem danos estéticos e retóricos, um Rei Salomão, em todo o seu esplendor sapiencial, por um bem mais verossímil cidadão hierosolimitano, tão abastado quanto cultivado e propenso à reflexão metafísica.» (CAMPOS, 1991, p. 35-36). O autor constatou que nem na própria tradução do texto, coordenada por Ginsberg para inclusão nos «Ketthubim» a "substituição da convenção poética pelo dado filológico-documental é levada a efeito» pois o versículo 1,12 foi traduzido «king in Jerusalem».

${ }^{4}$ Sobre isto voltaremos um pouco mais adiante quando virmos o contexto histórico do livro.
} 
lado, há uma crítica, que nem sempre é tão sutil, contra o próprio Salomão. O texto de 4,13 é claro: "Mais vale um jovem pobre e sábio que um rei velho e insensato, que não sabe aceitar conselhos”. Isto adquire particular relevância se se considera que Salomão era tido como um modelo de sabedoria da antiguidade.

\section{A data do livro}

No livro de Qohélet não é possível encontrar alusão clara e direta a acontecimentos históricos específicos que permitam determinar a época em que foi escrito. Também não há nomes próprios (já vimos que "filho de Davi” é um recurso literário), como também é ineficaz qualquer tentativa de localizar o livro no tempo.5 Muito pelo contrário, o autor usa elementos literários que podem induzir a localizar sua obra numa época diferente da que foi escrita; os editores também fizeram sua parte neste sentido, e a tradição fez outra.

Porém há pistas e indícios que permitem determinar a época, mesmo que aproximadamente, em que o livro foi escrito:

I. A primeira pista que temos é a língua em que o livro foi escrito: hebraico, porém um hebraico tardio ${ }^{6}$, que representa o último estágio do desenvolvimento do hebraico da Tanak, que teve seu primeiro estágio, séculos antes, na redação da fonte Javista do Pentateuco.

A hipótese de que o livro foi escrito originalmente em aramaico, sustentada principalmente por Burkitt, Zimmerman, Torrey e Ginsberg, não pode ser mantida, como bem afirmou Gordis,7 principalmente por que as partes poéticas do livro (1,28 ; 3,1-8; 11,8-12-7) não parecem ser tradução, mas original: uma poesia traduzida dificilmente manteria o ritmo e assonância do texto. (BUTTRICK, 1956, p. 13-14).

\footnotetext{
${ }^{5}$ Sobre isto Martin Hengel disse: «One cannot read any direct allusions to individual historical events from Koheleth, but the language, with its strong Aramaic colouring which already paves the way for the Hebrew of the Mishnah, and the whole milieu of the book, suggest a very late date of composition». (HENGEL, 1974, p. 115).

${ }^{6}$ Conferir Barton (BARTON, 1908, p.52).

${ }^{7}$ Robert Gordis se manifestou sobre este tema basicamente nos seguintes artigos: The Original Language of Qohelet, Qohelet - Hebrew or Aramaic? e The Translation-Theory of Qohelet Re-Examined.
}

Horizonte, Belo Horizonte, v. 14, n. 42, p. 473-496, abr./jun. 2016 - ISSN 2175-5841 
Também seria muito difícil que uma tradução mantivesse o peculiar estilo e sintaxe do livro. ${ }^{8}$ Mas, também, se fosse tradução do aramaico, as palavras nessa língua, como possivelmente também as palavras do persa e do grego, 9 teriam sido traduzidas e não mantidas.

O mais provável é que o Qohélet foi escrito por alguém que sabia escrever hebraico, porém usava aramaico com certa frequência, talvez nas relações comerciais ou para se comunicar com aquela parte da população que não conhecia o hebraico. Assim é possível que as expressões e palavras do aramaico, que aparecem no texto, já tivessem sido incorporadas ao hebraico falado, e pouco a pouco foram passando para o hebraico escrito. O que é um forte argumento para a datação tardia do livro. Possivelmente o autor é da região norte, perto da fronteira linguística. ${ }^{10}$

Além disso há o dado arqueológico de Qumrã. Na Cova IV foram encontrados fragmentos em hebraico do livro de Qohélet (CRENSHAW, 1976, p.49). Considerando que estes fragmentos foram datados, segundo os métodos modernos, a meados do segundo século, seria muito difícil que nessa época já existisse uma tradução do livro, pois deixaria pouco espaço de tempo entre sua redação e a tradução. Isto implicaria que o livro chegou a ser tão popular que uma tradução para o hebraico era indispensável [Crenshaw, 1976, p.49].11 O que não parece provável. Por outro lado, a própria ficção literária do livro torna impossível um original aramaico, pois um “filho de Davi” (Salomão?) escrevendo nessa língua era simplesmente impensável.

\footnotetext{
${ }^{8}$ Conferir Crenshaw (CRENSHAW, 1976. p. 49).

${ }^{9}$ Para uma listagem das características linguísticas do Qohélet que encontram paralelos na língua grega. Conferir The Relation of "Qoheleth" to Grek Thought (BARTON. 1908. p. 32). Crenshaw questiona que expressões tais como «abaixo do sol» e «eu vi bom» sejam de influência grega, pois estas frases se encontram também na literatura semítica, e a última expressão é autenticamente hebraica (Renshaw, 1976, p. 49)

10 Olhando exemplos contemporâneos, podemos entender melhor o que pode acontecer com uma língua "nas fronteiras": o que acontece com o inglês e espanhol na fronteira San Diego/Tijuana (No México); ou com o português e espanhol na Ponte da Amizade nas cidades de Foz de Iguaçu/Ciudad del Este (no Paraguai). Os exemplos sobre isto são inúmeros, especialmente na Europa, onde cidades de fronteiras falam até 3 idiomas.

${ }^{11}$ Robert Gordis se pronunciou veementemente contra o pretendido original aramaico nos seguintes artigos: The Original Language of Qohelet, Qohelet - Hebrew or Aramaic? e The Translation-Theory of Qohelet Re-Examined.
} 
1. Algumas das palavras, formas e construções próprias do aramaico que se encontram no livro são as seguintes: ${ }^{12}$

הבל como construto em 1,2;

כבר 1,10 2,16 3,15 4,2 6,10 9,6;

ענין em 1,13 2,23.26 3,10 4,8 5,2.13;

תקן 1,15 7,13;

em 2,8; 5,7;

שכח 4,2;

על על-עמת ש-16;

em 5,18; 6,2;

מענה 5,19;

אלו 6,6;

תקיף 6,10;

em 7,14;

חשבין em 7,25.27; 9,10.

פשר em 8,1.

שלטון em 8,4.8

משלחת em 8,8.

עבד 9,1.

קרב em 9,18.

גומץ em 10,8.

${ }^{12}$ Utilizo basicamente os resultados da pesquisa de George Aaron Barton (BARTON, 1908, p. 52), o autor dá uma lista detalhada a) das formas, construções e palavras do aramaico, b) das palavras do persa, c) das formas e palavras idênticas com outras da Mishna, d) das formas próprias do hebraico tardio, e) da sintaxe do hebraico tardio, e f) do uso em hebraico de formas do grego.

Horizonte, Belo Horizonte, v. 14, n. 42, p. 473-496, abr./jun. 2016 - ISSN 2175-5841 
סכן em 10,9.

em 10,17.

מדע 10,20.

ילדות em 11,9.10.

em 12,3.

דרבנות em 12,11.

2. É possível encontrar pelo menos duas palavras do persa: פרדסים em 2,5; e פתגם em 8,11.

3. Há várias formas e palavras idênticas a outras da Mishna. ${ }^{13}$

4. Algumas formas do hebraico correspondem a um hebraico tardio. Exemplos:

A) Em 8,1 o artigo não é suprimido (síncope) após a preposição na palavra כהחכם.

B) Há uma tendência para contração em ון, como por exemplo, nas palavras:

יתרון = vantagem, lucro, benefício $(1,3 ; 2,11.13 ; 3,9 ; 5,8.15 ; 7,12 ; 10,10.11)$.

חשבון = cálculo, projeto, planejamento, conclusão, juízo (7,25.27; 9,10).

= Que tem poder ou autoridade, soberano $(8,14.8)$.

C) Há também uma tendência para contração em ות, como por exemplo, nas palavras:

רעות = ambicionar, esforçar-se (1,14; 2,16.26; 4,4.6; 6,9).

= insensatez, tolice (1,17; escrita com letra inicial o, em 2,3.12.13; 10,1.13).

\footnotetext{
${ }^{13}$ Conferir a nota no 6 da Introdução de Andre Barucq [BARUCQ 1969, p. 15]. Barton dá um bom número de exemplos. Como amostra cito os dois primeiros: a) - אי = "aflição," 4,10; 10,16. Conferir Mish. "Yebamoth» 13,7 e a referência em Ja. 43b. (Ja = Jastrow, Dict. of the Targ., Talm. and Midrashic Lit.). b) אביונה = alcaparra, 12,5. Conferir «Ma`aseroth» 4,6 etc. e Ja. 5b. (Barton, 1908, p. 52).
} 


$$
\begin{aligned}
& \text { הוללות = loucura, fascinação (1,17; 2,12; 7,25; 9,3; 10;13). } \\
& \text { שפלות = ato de abaixar (as mãos), inatividade (10,18). } \\
& \text { ילדות = infância, juventude (11,9.10; também em Sl 110,3) }
\end{aligned}
$$

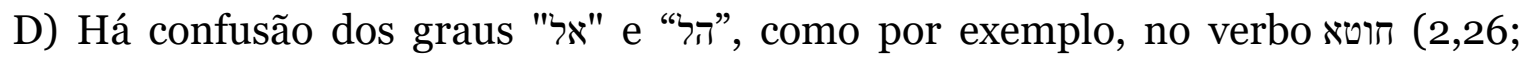
8,12; 9,2.18). Ver também o tratamento que o Qere dá as formas de (7,26; 10,5), ישנב (8,1).

F) O אנכי nunca aparece, sendo sempre 'אני

G). A palavra אספוה (12,11) só se encontra em 1Cr 26,15.17 e Ne 12,25, onde forma seu plural de uma maneira diferente.

5. Há formas da sintaxe que correspondem a um hebraico tardio. Exemplos:

A) O "waw" consecutivo com o imperfeito acorre somente três vezes $(1,17 ; 4,1.7)$, sendo que a construção com particípio é mais frequente. $(1,4.8 ; 2,14.19 ; 3,20.21$; 4,$5 ; 5 ; 7 ; 6,12 ; 8,12.14 .16 ; 9,5 ; 10,19$ etc.).

B) O particípio é frequentemente acompanhado por um pronome pessoal como seu sujeito. ${ }^{14}$ Exemplos:
a. זירח
b. הם שבים
c. מוצא אוי
d. יודץ אני $(8,12)$

C) Estas sentenças construídas com particípio são frequentemente negativas com אין $(4.17,9.2,11.5) .{ }^{15}$

\footnotetext{
${ }^{14}$ Mishna, Nedarim, 11,7. (BARTON, 1908, p. 52).

${ }^{15}$ Mishna, Naz., 2,4 (BARTON, 1908, p. 52)
} 
D) As construções com pronome pessoal frequentemente ocorrem com adjetivos verbais:
a. אני $(2,18)$
b. הוא $(2,22)$
c. יננו חסר $(6,2)$
d. איננו מלא (1,7)

E) אני é frequentemente usado pleononasticamente com a primeira pessoa do verbo: 16
a. אמרתי אני
b. איתי אני $(2,13.24 ; 5,17)$

F) As formas - באשר e = "porque" $=$ = "porque" (7,2; 8,4) são caraterísticas do hebraico tardio.

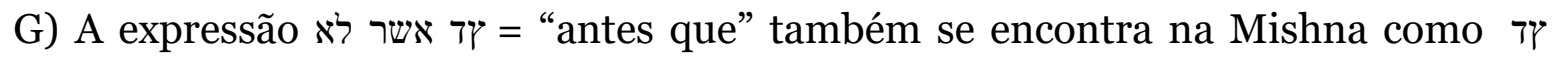
שלא, "Berakoth", 3,5.

II. Duas passagens têm sido frequentemente citadas como contendo fatos históricos, e por isso válidos para datar o livro:

a. O primeiro é o texto de 4,13-16:

"melhor menino pobre e sábio

que um rei velho e insensato,

que não aceita conselhos.

Pois da casa dos acorrentados

saiu para reinar,

${ }^{16}$ Barton remete também aos versículos 1,16; 2,11.12.13.14.18.20.24; 3,17; 4,1.7; 8,15 etc., e à Gramática de Gesenius $135 \mathrm{~b}$. 
pois enquanto reinava

nasceu pobre"

A Bíblia de Jerusalém comenta que este é um texto obscuro e de difícil tradução. Concordamos. Haroldo de Campos, que traduziu a última parte do v. 3 “que já não mais sabe iluminar-se", juntamente com concordar que é um texto obscuro, enigmático, e de tradução controversa, dá uma boa listagem das diferentes traduções por ele consultadas e um bom resumo da problemática (CAMPOS, 1991, p. $137-139) \cdot{ }^{17}$

Para saber se este texto serve para determinar a data do livro, bastaria saber quem é o menino pobre e sábio, e quem é o rei rico que nasceu pobre e que saiu do cárcere para reinar. Nisto reside precisamente o problema. Porém, primeiramente nos parece pertinente perguntar se o Qohélet está-se referindo a acontecimentos concretos, a casos típicos, ou é uma história que ele criou para assim poder ilustrar seu profundo pessimismo no que se refere ao poder.

Muitos comentadores têm tentado identificar quem é o velho rei e seu jovem sucessor. A tradição mishnânica os identificou como sendo Nemrod e Abraham. Outros viram neles Onias e seu sobrinho José, Ptolomeu III e Selêucida II, Antíoco III e Ptolomeu IV Filopator, Antioco Epifanes (175-164) e Demetrius I ou Alexandre Balas (150-145), 18 ou Antioco e seu filho Alexandre etc. ${ }^{19} \mathrm{Ou}$, procurando na história antiga de Israel, outros sugeriram que estas personagens correspondem à história de José e sua passagem da prisão para o trono no Egito, ou a Saul e Davi, ou Roboão e Jeroboão.

\footnotetext{
17 Vale acrescentar que Ravasi traduziu o v. 13 «O jovem, nascera pobre durante seu reinado e do cárcere saíra para se tornar rei». A tradução Ecumênica (São Paulo, Loyolas, 1994) traduziu «Pode o menino ter saído da prisão para o trono, ou até nascido mendigo e vir a reinar». Para maiores detalhes sobre a problemática pode ser consultado o texto de Torrey (TORREY, 1952, p. 175-177).

${ }_{18}^{18}$ Porém o autor afirma que "This view I for a time adopted, but the external evidence just passed in review compelled me to abandon it», e que a teoria de que se trata de Antíoco Epifanes e Demetrius, elaborada por Winckler, é insustentável porque é claro que Qohélet viveu antes que Ben Sirac (BARTON, 1908, p. 61).

${ }^{19}$ Para as citações das obras dos diferentes comentaristas conferir o livro de Robert Gordis (GORDIS, 1951, p. 65).
} 
Porém considerando que para cada nome proposto há uma boa quantidade de objeções, apoiamos Gordis, que concluiu que:

Em suma, se a passagem foi concebida como uma referência a um evento real, que poderia ter sido claro para os contemporâneos de Qohélet; ele certamente não combina com nenhuma das figuras históricas conhecidas por nós, e não pode ser utilizada para datar o livro. ${ }^{20}$ (GORDIS, 1951, p. 67, tradução nossa).

E com Ravasi que afirma que Qohélet:

Usando o esquema narrativo de José, constituiu, na realidade, apenas um caso "típico", uma parábola de valor universal, na qual se transfiguram também hipotéticas alusões concretas. (RAVASI, 1993, p. 142).

b. O segundo texto que geralmente é considerado como contendo alguma alusão histórica é o de 9,14-15:

Cidade pequena, e nela poucos habitantes, e marchou contra ela um grande rei, e cercou-a, e armou contra ela grandes obras de assédio.

E se encontrou nela um homem pobre, um sábio, e ele colocou em segurança a cidade, com sua sabedoria, porém ninguém lembrou o homem, a esse pobre.

Se fosse possível identificar qual é a cidade, quem é o grande rei, e quem é o homem pobre e sábio, teríamos aqui um material valioso para determinar a possível data do texto. Porém essa informação se perdeu no tempo, e hoje, com base nos dados que temos, é impossível recuperá-la. A história dos estudos sobre o Qohélet está cheia de pesquisadores que tentaram identificar o texto historicamente, porém até agora ninguém conseguiu solucionar o problema. Assim, por exemplo, foi sugerido que a cidade poderia ser Doar, sitiada sem sucesso por Antíoco o Grande, em 218, mas falta localizar o "homem pobre" na

\footnotetext{
20 "In sum, if the passage were intended as a reference to an actual event, it might have been clear to Koheleth's contemporaries; it surely does not suit any historical figures known to us, and cannot be utilized to date the book".
}

Horizonte, Belo Horizonte, v. 14, n. 42, p. 473-496, abr./jun. 2016 - ISSN 2175-5841 
história. ${ }^{21}$ Não há na historia conhecida um evento histórico que se encaixe nos fatos relatados pelo Qohélet. ${ }^{22}$

III. Considerando que o Sirácidas conhecia o Qohélet, ${ }^{23}$ se conclui que o Sirácidas tem que ser posterior ao Qohélet. Por isto é importante primeiramente determinar a data de origem dessa obra. No seu comentário sobre Siracidas, Antonino Minissale afirma que:

Convencionalmente se coloca a data de origem da obra em torno de 190, mas, tratando-se de livro que reúne o trabalho de toda uma vida, pode-se pensar nos anos 200-180 ou um pouco antes. (MINISSALE, 1993, p.20)

Pela sua vez Ney Brasil Pereira nos disse que a data do Sirácida pode ser estabelecida com bastante certeza por volta de 190-180 a.C. (PEREIRA, 1992. p. 14). Este período de dez a vinte anos, que é praticamente confirmado por todos os comentários sobre o Sirácida, é o terminus ad quem para a datação do Qohélet. Ou seja, o Qohélet não poderia ter sido escrito após o ano 180 a.C. Por este motivo não há no Qohélet menção nem da perseguição de Antíoco IV nem, da guerrilha dos Macabeus.

Mas se se considera que um livro da época deveria ter levado uns cinquenta anos para ser conhecido e aceito como escritura, e desta maneira ser usado pelo Sirácidas, podemos levar a data para aproximadamente o ano 250 a.C. ${ }^{24}$

\footnotetext{
${ }^{21} \mathrm{O}$ autor cita também várias outras tentativas de identificação. [GORDIS, 1951, p. 66].

${ }^{22}$ Todos os comentários consultados dedicam espaço, quando tentam localizar cronologicamente o livro, a esta passagem. Assim, por exemplo (BARTON, 1908, p 60-63). Há outros textos nos quais alguns tem pensado encontrar referências históricas, como por exemplo 10,16-17; 8,2-5; porém estes textos devem ser considerados mais como modelos ou exemplos típicos da sabedoria tradicional, eles são tão gerais que praticamente é impassível localizá-los num determinado evento, ou pelo contrário eles podem ser identificados com um número enorme de eventos (BUTTRICK , 1956, p. 14).

${ }^{23}$ Conferir: The Relation of Eclesiastes to Ben Sira. [BARTON, 1908, p. 53]. Aqui o autor coloca lado a lado, em forma de colunas, os textos do Qohélet citados pelo Sirácida. Divide estes textos em três tipos: 1) passagens existentes no texto hebreu do Sirácidas, que mostram forte dependência do texto hebreu do Qohélet; 2) passagens que não se encontram no texto hebreu de Sirácida, mas no texto grego, porém com forte indicio de que são uma tradução do texto hebreu do Qohélet, pois são praticamente idênticas; c) passagens nos quais o Sirácida parafraseou o texto do Qohélet, porém mostrando uma forte dependência dele. Ney Brasil Pereira em seu comentário sobre Sirácidas afirma que "Com o Eclesiastes, o Sirácidas tem uma relação polêmica, reafirmando o princípio, deuteronomista da retribuição contra o pessimismo desse autor; e o princípio do duplo aspecto das coisas, antecipado agnosticamente em Ecl 3 e 7, é uma das peças chaves da teodicéia siracidiana» [Pereira, 1992, p. 19]. Esta opinião de Ney Brasil Pereira está baseada no comentário de Minissale de 1988 (MINISSALE, 1993, p. 96). Também conferir Qoheleth y el Pensamiento Judio (BARUCQ, 1969, p. 191-192).

${ }^{24}$ Esta data também é confirmada por Ivo Storniolo e Euclides Balancin (STORNIOLO; BALANCIN, 1990. p. 8).
}

Horizonte, Belo Horizonte, v. 14, n. 42, p. 473-496, abr./jun. 2016 - ISSN 2175-5841 
Um outro dado a este respeito é a Cova IV de Qumrã, onde foram encontrados fragmentos do livro de Qohélet, que formavam parte de um rolo escrito por volta de meados do segundo século. Se o livro necessitou de várias décadas para ser aceito nos estritos círculos ortodoxos dos escritores dos Rolos do Mar Morto, não deve ter sido escrito após o ano 200, aproximadamente.

IV. Muito mais difícil é determinar o terminus a quo. Porém, considerando que o livro foi escrito num hebraico tardio, quase com certeza pós-exílico, que há duas palavras do persa, que há influência da língua grega e a ausência dos pensadores gregos, podemos estabelecer como terminus a quo as conquistas de Alexandre.

Porém se se considera que teriam sido necessárias algumas décadas para que o grego fosse familiar aos moradores da Palestina, de tal modo que pudessem usá-lo em sua literatura, podemos levar a data até meados do $3^{0}$ século, ou seja, 250 a.C. data que coincide - como vimos no item anterior - com a estabelecida a partir do Sirácida.

Ravasi pensa que os três termos políticos "melek" = rei, "mosel" = que domina, e "sallit" = poderoso, não remetem ao reino helenístico em geral, nem aos soberanos Ptolomeus de Alexandria, mas à situação palestinense do séc. III a.C., na qual se distinguia entre uma corte real e um sistema burocrático aberto também à classe alta judaica ( RAVASI, 1993, p. 15).

Storniolo e Balancin também pensam que todos os indícios levam a crer que o autor escreveu em meados do século III a.C., provavelmente pelo ano 250 a.C. Eles vão além e afirmam que o livro "reflete a situação histórica e as condições sociais em que vivia o seu povo na Palestina” (STORNIOLO; BALANCIN, 1990, p. 8).

Assim, o ano 250 a.C. - aproximadamente - é a data que nos parece mais provável para o origem do Qohélet, porém estamos conscientes de que esta obra 
poderia ter sido escrita um século antes, ou até um pouco mais atrás ainda. Ou seja, o intervalo em que esta obra poderia ter sido escrita se situa por volta do ano 400 até o 200 a.C., não havendo argumentos conclusivos para negar a datação em qualquer ponto desse período.

Um consenso só tem sido estabelecido em dois pontos: o Qohélet é pósexílio e é anterior ao Sirácida, sendo esta última obra a única que pode ser localizada, com certa segurança, no período grego. Porém se houvesse dúvida sobre a data do Síracida ou mesmo se ele conhecia o Qohélet, o "terminus ad quem” definitivo é o ano 100 a.C. que corresponde ao limite de datação, no sentido de proximidade a nós, do fragmento de Qohélet encontrado na cova IV de Qumrã.

\section{0 lugar geográfico do livro}

Mitchell Dahood, numa série de $\operatorname{artigos}^{25}$ escritos entre os anos 1952 a 1966, lançou a teoria de que o cenário do livro era a Fenícia. O motivo para isto eram os múltiplos termos comerciais contidos no interior da obra, como também a ortografia: tratar-se-ia de um autor que escreveu em hebraico usando a ortografia fenícia. Para Dahood a influência literária do dialeto norte-palestinense, língua muito próxima do fenício, era evidente (BARUCQ, 1969, p. 16). Com base nisso, Dahood situava a obra no norte de Israel, senão na própria Fenícia. Dahood chegou até afirmar que Qohélet poderia ter vivido numa cidade fenícia do litoral. Porém se esta tese teve o apoio de vários estudiosos, especialmente dos conhecedores do ugarítico, ${ }^{26}$ ela tem sido questionada por muitos outros estudiosos. ${ }^{27}$

\footnotetext{
${ }^{25}$ Alguns destes artigos de Mitchell Dahood são os seguintes: Qoheleth and Recent Discoveries, The Language of Qohelet, CanaanitePhoenician Influence in Qohelet, The Phoenician Background of Qoheleth, The Phoenician Contribution to Biblical Wisdom.

${ }^{26}$ Ravasi cita alguns estudos que apoiaram a tese de Dahood (RAVASI, 1993, p. 14).

${ }^{27}$ Como por exemplo Robert Gordis em Was Kohelet a Phoenician? (GORDIS, 1955, p. 103-114). Barucq chama a atenção para o perigo de "cargar ciertos términos de un sentido que no tienen en la lengua literária bíblica y el perigo de ser oscuro» (BARUCQ, 1969, p. 16). Crenshaw afirma que «This theory of the book's origin has made little impact on the scholarly community» (CRENSHAW, 1976, p. 49). Por por sua vez Sellin e Fohrer afirmam: «Mas o seu vocabulário, com base no qual Dahood pretende provar a existência de um ambiente comercial, contém, até quase à metade, um fundo vocabular comum, enquanto o modo de escrever sem "matres lectionis" certamente era desconhecido no hebraico da época de Qohélet. » (SELLIN-FOHRER, 1977, p. 503).
} 
Outros pesquisadores, ${ }^{28}$ tendo em conta os fenômenos naturais que são descritos em 1,5-7, pensaram que o lugar do livro era o Egito. Porém esta hipótese é fraca, com pouco fundamento e não recebeu apoio da grande maioria dos estudiosos do tema. Até houve quem pensasse que o lugar do livro era a diáspora oriental.

Muito mais provável é que o livro teve sua origem na Palestina. Há uma boa quantidade de evidência interna na obra que apoiaria este ponto de vista. Vejamos:

- Em 2,6 se fala de reservatórios de água.

- Em 10,8s se mencionam os muros, os fossos e o trabalho com pedras.

- Em 10,18 se fala das vigas do teto.

- Em 12,6 se fala de poços e fontes.

- Em 11,4 há uma preocupação com o vento, as nuvens e a chuva. (também em 12,2)

- Em 4,17 e 8,10 é mencionado o templo, e em 5,5 o sacerdote.

Considerando que a maioria dos elementos listados podem formar parte praticamente de qualquer cidade do Antigo Oriente Médio, só esta última referência ao ambiente do templo seria o principal indício para localizar o texto em Jerusalém. 


\section{Conclusão}

No início deste artigo indicamos que nosso objetivo era pesquisar a data, o autor e o local em que foi escrito o livro de Eclesiastes. E foi isso que fizemos. Analisamos fontes biográficas, algumas delas provenientes da antiguidade, que nos permitem responder as perguntas que norteavam nossa pesquisa.

A primeira coisa que devemos ressaltar nesta conclusão é que sobre estes temas não há respostas definitivas ou que não mereçam objeções. Sobre isto é muito mais fácil afirmar o que não poderia ter sido, isto é, dar respostas negativas, que responder objetiva e categoricamente as perguntas propostas.

Assim, temos clareza que as respostas às perguntas formuladas poderiam receber um bom número de objeções. Mas também temos a certeza que são as respostas com maiores possibilidades de serem verdadeiras e as que têm as melhores chances de resistir à crítica.

Então, a que respostas chegamos?

Sobre a data: por todo o exposto anteriormente consideramos que a data da redação do livro de Qohélet é algo em torno do ano 250 a.C. Nisto concordamos com Gordis.

Sobre o autor: A autoria do livro não pode ser de Salomão, mas de alguém que viveu no norte da Palestina, na fronteira linguística com o aramaico. Possivelmente um homem de uma boa condição econômica, com uma formação intelectual bastante apurada e de agudo senso crítico e teológico.

Sobre o local: devemos dizer que este foi o aspecto mais difícil de determinar. Mas pela evidência exposta, da qual o argumento mais forte é a menção do templo, podemos afirmar que o livro foi escrito em Jerusalém. 
E finalmente queremos assinalar, após este estudo, o importante que é, para a compreensão da mensagem de um texto bíblico, a contextualização históricogeográfica e cultural.

Assim, concluímos nosso artigo com a esperança de ter feito uma contribuição pertinente e relevante no campo dos estudos bíblicos brasileiros.

\section{REFERÊNCIAS}

BARTON, George Aaron. A Critical and Exegetical Commentary on the Book of Ecclesiastes. New York: Charles Scribner's Sons, 1908.

BARUCQ, Andre. Eclesiastes, Qoheleth. Texto y Comentario. Madrid: Ediciones Fax, 1969.

BARUQ, Andre. Ecclesiaste. Paris: Beauchesne, 1968.

BICKERMAN, Elias J. The Jews in the Greek Age. Cambridge: Harvard University Press, 1988.

BUTTRICK, George A. (Editor). The Interpreter's Bible, V.5: Ecclesiastes, Song of Songs, Isaiah, Jeremiah. New York, Abingdon Press, 1956.

CAMPOS, Haroldo de. Qohélet = o-que-sabe: Eclesiastes: poema sapiensal. São Paulo: Perspectiva, 1991.

CHARPENTIER, Etienne. As Raizes da Sabedoria. São Paulo: Paulinas, 1983.

CIOFFARI, Vicenzo. Fortune and fate from Democritus to St. Thomas Aquinas. New York, 1935.

COX, Samuel. The Book of Ecclesiastes. New York: A.C. Armstrong and Son, 1898.

CRENSHAW, James L. Eclesiastes. London: S \& M, 1976.

DAHOOD, Mitchell. Qoheleth and Recent Discoveries. Biblica, v.39, n.3, p. 302-318, 1958.

DAHOOD, Mitchell. The Language of Qohelet. Catholic Biblical Quarterly, v.14, p. 277$232,1952$. 
DAHOOD, Mitchell. Canaanite-Phoenician Influence in Qohelet. Biblica, v. 33, p. 30-52, 1952.

DAHOOD, Mitchell. The Phoenician Background of Qoheleth. Biblica, v.47, p. 264-282, 1966.

DAHOOD, Mitchell. The Phoenician Contribution to Biblical Wisdom. In: The Role of the Phoenicians in the Interaction of Mediterranean Civilizations. Ed. by W.A. Ward. Beirud: American University of Beirut, 1968, p. 123-148.

ELLUL, Jacques. La Raison d'être - Méditation sur l'Ecclésiaste. Paris: Seuil, 1987.

FARMER, Kathleen A. Proverbs \& Ecclesiastes. Who Knows What is Good?.

Edinburgh: The Handsel Press, 1991.

GATTINONI, Carlos T. El Sentido de la Vida, reflexiones sobre el Eclesiastés. Buenos Aires: Aurora, 1990.

GLASSER, Etiene. O processo da felicidade por Qoelet. São Paulo: Paulinas, 1975.

GORDIS, Robert. Koheleth, the man and his world. New York: Schocken Books, 1951.

GORDIS , Robert. Was Kohelet a Phoenician?. Journal of Biblical Literature, Boston, v. 74, p. 103-114, 1955.

GORDIS , Robert. The Original Language of Qohelet. JQR, London, v.37, p. 67-84, $1946 / 1947$.

GORDIS , Robert. Qohelet - Hebrew or Aramaic?. Journal of Biblical Literature, Boston, v.71, p. 93-109, 1952.

GORDIS , Robert. The Translation-Theory of Qohelet Re-Examined. JQR, London, v.39, p. 103-116, 1949.

GOTTWALD, Norman K. Introdução Socioliterária à Bíblia Hebraica. São Paulo: Paulinas, 1988.

HENGEL, Martin. Judaism and Hellenism. Philadelphia: Fortress Press, 1974.

HENGEL, Martin. Jews, Greeks and Barbarians. Philadelphia: Fortress Press, 1980.

HUBBARD, David Allan. Muito Além da Futilidade, mensagem de esperança do livro de Eclesiastes. Belo Horizonte: Missão, 1991.

MICHAUD, Robert. Qohelet y el helenismo. Estella: Verbo Divino, 1988.

MINISSALE, Antonino. Sirácidas, as raízes da tradição. São Paulo, Paulinas. 1993. 
MURPHY, Roland E. The forms of the Old Testament Literature. Vol. XIII:

Wisdom, Canticles, Ecclesiastes, Esther. Grand Rapids: Eerdmans, 1981.

PEREIRA, Ney Brasil. Sirácidas ou Eclesiástico, A Sabedoria de Jesus, filho de Sirac. Petrópolis, Sinodal-Metodista-Vozes, 1992.

PODECHARD, E. L'Eclesiaste. Paris: 1912.

RAD, Gerhard Von. Sabiduría en Israel: Proverbios, Job, Eclesiastés, Eclesiástico, Sabiduría. Madrid: Cristiandad, 1985.

RAVASI, Gianfranco. Qoheleth. São Paulo: Paulinas, 1993.

RODRIGUEZ, Jecy. Vivencias do Povo de Deus; O Eclesiastes. Petrópolis: Vozes, 1976.

SCHÖKEL, Luis Alonso. Diccionario Biblico Hebreo-Español. Madrid: Editorial Trotta. 1994.

SELLIN-FOHRER. Introdução ao Antigo Testamento. São Paulo, Paulinas. 1977

SOUZA, Marcelo de Barros e CARAVIAS, Jose L. Teologia da terra. Petropolis: Vozes, 1988.

STEPHANUS, Irene. Eclesiastés o Qohelet y una propuesta de hermenéutica para la ciudad a partir del rock nacional. 1991. (Tesis de licenciatura) - ISIDED, Facultad de Teología, Buenos Aires.

STORNIOLO, Ivo; BALANCIN, Euclides Martins. Como Ler o Livro do Eclesiastes Trabalho e Felicidade. São Paulo: Paulinas, 1990.

TRANCHARD BARRAT, Ernesto. Eclesiastés. Madrid: Iglesia Evangélica, 1980.

TORREY, Ch. C. The Problem of Ecclesiastes 4,13-16. Vetus Testamentum , Leiden, n.2, p. 175-177, 1952.

WERNER, Charles. La nature et le hasard. In: La Philosophie Grecque. Paris: Payot, 1972. 